\title{
Stage II Colorectal Cancer AJCC v8
}

National Cancer Institute

\section{Source}

National Cancer Institute. Stage // Colorectal Cancer AJCC v8. NCI Thesaurus. Code C134186.

Stage II includes: IIA: T3, N0, M0; IIB: T4a, N0, M0; IIC: T4b, N0, M0. T3: Tumor invades through the muscularis propria into pericolorectal tissues. T4a: Tumor invades through the visceral peritoneum (including gross perforation of the bowel through tumor and continuous invasion of tumor through areas of inflammation to the surface of the visceral peritoneum). T4b: T umor directly invades or adheres to adjacent organs or structures. N0: No regional lymph node metastasis. M0: No distant metastasis. (AJCC 8th ed.) 